\title{
Analisis Daya Saing SDM dalam Upaya Meningkatkan Prestasi Berusaha Pengusaha Industri Kecil di Kota Pekanbaru
}

\author{
FATKHURAHMAN \\ Dosen tetap Sekolah Tinggi Ilmu Ekonomi Riau \\ email: fatkhurahmanq8@yahoo.com
}

\begin{abstract}
The purpose of this study was to determine the effect of competitiveness towards achievements to strive in a small industrial town of Pekanbaru. Whole object of this study is the small industrial entrepreneurs registered in the city of Pekanbaru the number of 1,545 people spread on five business groups namely food industry business, clothing, chemicals and building materials, metals and electronics and handicrafts. Therefore, the relative amount of the population defined as 94 samples using proportional random sampling method. The variables studied consisted of three independent variables and the dependent variable. The independent variable is competitiveness and while the dependent variable was trying achievement. The method used in this study is a quantitative method. The instrument used for data collection in the form questionnaire Likert scale models. Discussion and hypothesis testing are conducted through the processing path analysis techniques using SPSS 17. The results showed that the effect on the competitiveness of small entrepreneurship in the industry by entrepreneurial achievements of trying to influence the small industrial city of Pekanbaru with coefficient of 0,555. competitiveness of trying to influence the achievement of small industries in the city of Pekanbaru with the influence of competitiveness on the achievement represented by the coefficient beruasha meaningful reasons for wanting to be successful because it has the potential to succeed as a capital for entrepreneurs trying to businesses gain increasing and also the products more efficient.
\end{abstract}

Keywords :Competitiveness, Achievement Sought

Prestasi atau dikenal juga dengan kinerja merupakan hasil yang diperoleh dari sebuah kegiatan atau pekerjaan. Pada ilmu manajemen sumber daya manusia prestasi merupakan suatu capaian yang akan dicapai dan ditingkatkan perolehannya dari masa ke masa, melalui berbagai macam daya dan upaya. Hal ini juga merupakan tanggung jawab secara keilmuan dari bidang ilmu manajemen sumber daya manusia dalam menjawab persoalan tersebut. Pekerjaan setiap manusia berbeda dalam rangka menghasilkan produk yang pada akhirnya adalah untuk mendapatkan hasil dan atau kepuasan dalam memenuhi kebutuhan hidupnya. Seseorang akan melakukan kegiatan dengan seksama, manakala mereka menyadari akan arti pentingnya pekerjaan dilakukan dan peruntukannya. Terdapat banyak pekerjaan yang dilakukan seseorang dalam tujuan tersebut, seperti: bekerja di perusahaan maupun lembaga pemerintah, kemudian bekerja secara mandiri seperti membuka usaha sendiri. Namun saat ini yang lebih didorong pemerintah adalah menumbuhkan jiwa kewirausahaan bagi generasi sekarang dengan tujuan mampu membuka usaha sendiri yang pada akhirnya akan menjadi mandiri.

Hal ini terjadi di Amerika Serikat pada tahun 1980 an telah lahir sebanyak 20 juta wirausahawan baru, mereka menciptakan lapangan pekerjaan baru. Demikian pula di Eropa Timur Wirausahawan bermunculan dan bahkan di China yang masa lalu menganut paham komunisme murni, kini mulai membuka diri terhadap lahirnya wirausahawan baru dan menerima investasi dari luar. Kemandirian dalam berusaha memberikan kesempatan bagi diri sendiri untuk berkembang dan pada gilirannya akan mampu menciptakan lapangan pekerjaan. Hal ini juga akan mampu memberikan kontribusi positif terhadap masalah yang dihadapi 
pemerintah yakni pengangguran. Terdapat berbagai jenis usaha yang ditekuni oleh masyarakat seperti usaha dagang baik barang maupun jasa, kemudian usaha industri dengan berbagai aneka industri yang ada. Usaha ini dengan berbagai skala yang dimiliki, seperti skala mikro, kecil dan menengah serta besar.

Dalam penelitian ini memilih usaha sektor industri skala kecil yakni dengan pertimbangan bahwa usaha sektor industri kecil merupakan bentuk usaha yang banyak dalam arti jumlah menyerap tenaga kerja dibandingkan dengan sektor jasa. Kemudian penelitian dilakukan di kota Pekanbaru, karena daerah ini merupakan salah satu kota besar di Indonesia yang memiliki jumlah industri kecil yang relatif banyak dan juga secara geografis berlokasi sangat strategis yakni terletak di perbatasan Negara tetangga (Malaysia dan Singapura) menyebabkan memiliki peluang pemasaran dan yang lebih baik.

Kota Pekanbaru merupakan Ibukota Propinsi Riau, yang semula dikenal dengan sebutan Dusun Payung Sekaki yang terletak di tepi sungai Siak dan secara geografis berlokasi sangat strategis yakni terletak di perbatasan Negara tetangga (Malaysia dan Singapura) menyebabkan Kota Pekanbaru menjadi kota perdagangan dan memiliki daya tarik tersendiri bagi berbagai kelompok serta memiliki visi yakni "Terwujudnya Kota Pekanbaru Sebagai Pusat Perdagangan Dan Jasa, Pendidikan serta Pusat Kebudayaan Melayu, Menuju Masyarakat Sejahtera yang berlandaskan Iman dan Taqwa".

Visi kota tersebut untuk dapat mewujudkannya tidak terlepas dari peran sumber daya manusia yang dimiliki kota ini. Penduduk menjadi sumber daya manusia yang paling berperan, karena penduduk merupakan aset bagi kota yang memberikan warna dan harapan serta ancaman jika tidak dikelola dengan baik. Penduduk kota pekanbaru dari tahun ke tahun terus mengalami peningkatan. Berdasarkan data dari BPS Kota Pekanbaru jumlah penduduk tahun 2010 sebanyak 897.768 jiwa dan tahun 2011 sebanyak 937.939 jiwa, mengalami pertambahan sebanyak 40.171 jiwa (4.47\%) ini berarti lebih tinggi apabila dibandingkan dengan laju pertumbuhan penduduk secara nasional yakni $1,17 \%$ per tahun.

Hal ini juga yang menyebabkan persaingan kerja yang ketat di kota Pekanbaru, berdasarkan data bahwa pada tahun 2011 pencari kerja berjumlah 16.941 orang. Sedangkan lowongan yang tersedia hanya 4.953 atau $29,2 \%$. Oleh karenanya sebagian dari penduduk di daerah ini sebagai sumber daya manusia memilih membuka usaha. Usaha yang berkembang didominasi oleh usaha kecil khususnya pada usaha industri kecil dan perdagangan.

Menurut SK Mentri Perindustrian dan Perdagangan No.254/MPP/7/1997, usaha industri kecil adalah industri yang memiliki nilai investasi perusahaan sampai dengan $\mathrm{Rp}$ 200 juta (tidak termasuk tanah dan bangunan) dan pemiliknya warga negara Indonesia. Sedangkan menurut BPS berdasarkan jumlah tenaga kerja yaitu tenaga kerja 5 sampai dengan 19 orang. Usaha ini juga dibedakan menjadi usaha kecil formal dan informal, usaha kecil formal yaitu usaha kecil yang telah terdaftar pada badan atau lembaga resmi dan telah berbadan hukum atau telah memiliki izin usaha. Sedangkan usaha kecil informal adalah merupakan usaha yang belum terdaftar atau belum tercatat serta belum berbadan hukum, seperti pedagang kaki lima (PKL). Usaha industri kecil informal tidak memiliki data yang jelas bila dibandingkan dengan sektor formalnya sudah dicatat oleh pemerintah yang berwenang.

Pada usaha industri kecil ini, dalam penelitian ini melihat dari sisi perkembangan usaha, penyerapan tenaga kerja dan jumlah investasi. Karena industri kecil merupakan usaha yang memiliki prestasi terhadap gelombang krisis ekonomi di tahun 1997 dalam bertahan dan dalam menyerap tenaga kerja serta dalam usaha menyelamatkan perekonomian bangsa Indonesia. Berdasarkan data empirik tentang industri kecil yang diperoleh melalui BPS kota Pekanbaru dilihat dari perkembangan industri kecil di kota Pekanbaru tahun 2007-2011, 
diketahui perkembangan industri kecil dilihat dari tahun 2007 - 2011 cenderung berfluktuasi dimana pada tahun 2008 menurun sebesar $40 \%$, namun kemudian unit usaha meningkat sebesar 9,2\% pada tahun 2011. Kemudian dapat pula dilihat perkembangan usaha dan penyerapan tenaga kerja serta investasi yang ditanamkan tahun 2007-2011.

Usaha kecil dalam menyerap tenaga kerja dan investasi mengalami penurunan khususnya dalam hal penyerapan tenaga kerja menurun seperti dapat dilihat pada tahun 2010 ke 2011 semula 1.559 orang menjadi 1.444 orang atau $7.4 \%$ dan investasi yang dilakukan menurun semula $\mathrm{Rp}$. 23.472.000.000 menjadi Rp. 20.854.698.000 atau sebesar $11.2 \%$. Dari fenomena prestasi berusaha industri kecil yang dilihat dari kemampuannya berkembang, menyerap tenaga kerja dan pengembangan investasinya maka dapat dikatakan adanya kesenjangan dimana prestasi berusaha pengusaha pada industri kecil yang menurun khususnya dalam penyerapan tenaga kerja dan juga investasi yang ditanamkan, hal ini juga menunjukkan ketidakpastian dan menurunnya kelangsungan hidup dari usaha sektor industri kecil dimasa mendatang.

Kebijakan tenaga kerja terkait erat dengan strategi pengembangan ekonomi dan kebijakan stabilitas sosial. Dan keberhasilan pada satu sisi suatu kebijakan tergantung pada keberhasilan yang lain. Unsur-unsur interaksi mempengaruhi keberhasilan kebijakan tenaga kerja meliputi seberapa baik kebijakan itu sejalan dengan seluruh strategi pengembangan ekonomi, yang juga harus membangun jejaring dengan layanan organisasi ekonomi dan sosial lain, dan bagaimana kondisi sosial dan ekonomi mempengaruhi fleksibilitas implementasinya. Industri kecil pemula menjadi penghela penciptaan tenaga kerja di tingkat lokal. Penumbuhan Industri kecil pemula mempunyai andil penting dalam penyusunan kebijakan tenaga kerja diberbagai wilayah. Agar kebijakan Industri kecil pemula berjalan dengan baik, otoritas pemerintah daerah harus melibatkan mereka dalam setiap proses penyusunan dan implementasi kebijakan.

Pemerintah kota Pekanbaru dalam rangka meningkatkan kemampuan berusaha mendirikan BPTK (Balai Pelatihan Tenaga Kerja), lembaga ini didirikan dengan menjalin kerjasama dengan dunia usaha dan juga kalangan perguruan tinggi. Pemerintah kota Pekanbaru juga menganjurkan masyarakat untuk berwirausaha melalui program pendidikan dan pelatihan seperti SMK (43 sekolah) dan lembaga kursus serta BPTK (balai pelatihan tenaga kerja) yang memberikan pelatihan kewirausahaan kepada masyarakat dengan berbagai keahlian. Tentunya terdapat banyak faktor yang mempengaruhi prestasi berusaha pengusaha kecil, salah satunya yang diduga adalah variabel daya saing.

Berdasarkan beberapa pendapat ahli seperti menurut Panji Anoraga (2005: 50-52) pengertian prestasi berusaha adalah suatu tingkah laku sebagai keluaran (output) dari suatu proses berbagai macam komponen kejiwaan yang melatarbelakanginya atau menghasilkan lebih banyak, dan berkualitas lebih baik, dengan usaha yang sama.

Apabila dilihat dari makna kata menurut Leonardus Saiman (2009: 43) bahwa berusaha berasal dari kata usaha yang artinya menciptakan kegiatan atau bekerja atau pekerjaan dan atau berbagai aktivitas bisnis. Jadi berusaha adalah beraktivitas bisnis, berusaha juga sama artinya dengan bekerja namun bekerja dalam dunia bisnis.

Kemudian prestasi dapat diartikan sebagai hasil atau output dari pencapaian suatu maksud atau tujuan. Hal ini sebagaimana disampaikan oleh Mangkunegara (2005: 9) bahwa prestasi sama dengan kinerja adalah hasil kerja secara kualitas dan kuantitas yang dicapai oleh seseorang dalam melaksanakan tugasnya sesuai dengan tanggung jawab yang diberikan kepadanya.

Menurut Moh. Pabundu Tika (2010: 121-122) prestasi adalah pelaksanaan hasilhasil fungsi pekerjaan pada periode waktu tertentu. Hal in juga diperkuat oleh pendapat Edy Sutrisno (2010: 170) menyatakan bahwa 
prestasi kerja adalah kesuksesan seseorang dalam melakukan pekerjaan. Kemudian Menurut T. Hani Handoko (2001: 235), penilaian prestasi (performance appraisal) adalah proses melalui mana organisasiorganisasi mengevaluasi atau menilai prestasi kerja. Kegiatan ini dapat memperbaiki keputusan-keputusan personalia dan memberikan umpan balik kepada para karyawan tentang pelaksanaan kerja mereka. Berdasarkan pengertian-pengertian prestasi berusaha di atas maka dapat disimpulkan bahwa prestasi berusaha adalah suatu tingkah laku sebagai keluaran dari suatu proses berbagai macam komponen kejiwaan yang melatar belakanginya atau meghasilkan lebih banyak, dan berkualitas lebih baik, dengan usaha yang sama.

Menurut Henry Simamora (2004: mengidentifikasi setiap dimensi kinerja yang universal yang dapat diterapkan pada semua pekerjaan, adalah mungkin menentukan beberapa karakteristik yang harus dimiliki oleh kriteria apabila kriteria itu diharapkan bermanfaat bagi penilaian kinerja. Siswanto Sastrohadiwiryo (2005: 232) menyatakan prestasi kerja merupakan proses subjektif yang menyangkut penilaian manusia. Dikatakan penilaian kinerja subyektif, karena kebanyakan pekerjaan benar-benar tidak mungkin diukur secara objektif, hal ini disebabkan beberapa alasan, termasuk alasan kerumitan dalam tugas pengukuran, lingkaran yang berubah-ubah, dan kesulitan dalam merumuskan tugas dan pekerjaan individual tenaga kerja secara rinci. Dengan demikian, penilaian kinerja sangat mungkin keliru dan sangat mudah dipengaruhi oleh sumber yang tidak aktual. Tidak sedikit sumber tersebut mempengaruhi proses penilaian sehingga harus diperhitungkan dan dipertimbangkan dengan wajar. Penilaian kinerja dianggap memenuhi sasaran apabila memiliki dampak yang baik pada tenaga kerja yang baru dinilai kinerja/keragaannya.

Menurut Miner dalam Edy Sutrisno (2010: 172) secara umum dapat dinyatakan empat aspek dari prestasi kerja, yaitu sebagai berikut: Kualitas yang dihasilkan, menerangkan tentang jumlah kesalahan, waktu dan ketepatan dalam melakukan tugas. Kuantitas yang dihasilkan, berkenaan dengan berapa jumlah produk atau jasa yang dapat dihasilkan. Waktu kerja, menerangkan akan berapa jumlah absen, keterlambatan serta masa kerja yang telah dijalani individu. Kerjasama, menerangkan akan bagaimana individu membantu atau menghambat usaha dari teman sekerjanya.

Menurut Moh. Pabundu Tika (2010: 121) menjelaskan bahwa dimensi prestasi berusaha adalah produksi (keuntungan, penjualan, pangsa pasar, dokumen yang diproses, rekanan yang dilayani); efisiensi (perbandingan keluaran dengan masukan); kepuasan (sikap, kesejahteraan); ketidakpastian (persaingan, keinginan pelanggan, kualitas); kelangsungan hidup.

Berdasarkan uraian tentang dimensi prestasi berusaha di atas, maka dapat disimpulkan untuk mengukur prestasi berusaha menggunakan pendapat Moh. Pabundu Tika yang menyatakan bahwa dimensi prestasi berusaha antara lain: produksi (keuntungan, penjualan, pangsa pasar, dokumen yang diproses, rekanan yang dilayani); efisiensi (perbandingan keluaran dengan masukan); kepuasan (sikap, kesejahteraan); ketidakpastian (persaingan, keinginan pelanggan, kualitas); kelangsungan hidup.

Menurut Sopiah (2008; 23) bahwa faktor yang mempengaruhi prestasi kerja individu antara lain effort (usaha), ability (kemampuan) dan situasi lingkungan. Usaha manusia dalam bentuk motivasi, motivasi adalah kekuatan yang dimiliki manusia dan melahirkan intensitas dan ketekunan yang dilakukan secara sukarela dan ditujukan untuk mencapai tujuan. Ability atau kemampuan berbentuk kompetensi, individu yang kompeten memiliki pengetahuan dan keahlian, bakat dan keberanian.

Menurut Moh. Pabundu Tika (2010: 122) menjelaskan bahwa faktor-faktor yang mempengaruhi prestasi berusaha antara lain faktor internal (kecerdasan, ketrampilan, 
kestabilan emosi, motivasi, persepsi peran, kondisi keluarga, kondisi fisik seseorang dan karakteristk kelompok kerja) dan faktor eksternal (peraturan ketenagakerjaan, keinginan pelanggan, pesaing, nilai-nilai sosial, serikat buruh, kondisi ekonomi, perubahan lokasi kerja dan kondisi pasar).

Menurut Panji Anoraga (2005: 50-52) menjelaskan faktor yang mempengaruhinya prestasi antara lain faktor kepribadian dan lingkungan yakni kalau menginginkan prestasi bertambah tinggi maka perlu di "oprek-oprek" masalah lingkungan maupun kepribadiannya. Kemudian juga dijelaskan faktor lainnya adalah pekerjaan yang menarik, upah yang baik, keamanan dan perlindungan dalam pekerjaan, penghayatan atas maksud dan makna pekerjaan, lingkungan atau suasana kerja yang baik, promosi dan perkembangan diri mereka sejalan dengan perkembangan perusahaan, merasa terlibat dalam kegiatan organisasi, pengertian dan simpati atas persoalanpersoalan pribadi, kesetiaan pimpinan pada diri si pekerja dan disiplin kerja yang keras.

Menurut Surya Dharma (2005: 102) daya saing atau kompetensi menentukan aspek-aspek penilaian prestasi kerja. Kompetensi itu merupakan apa yang dibawa oleh seseorang ke dalam pekerjaannya dalam bentuk jenis dan tingkatan perilaku yang berbeda seperti pengetahuan, keahlian dan kepiawaian. Kemudian menurut Anwar Prabu Mangkunegara (2005: 67) mengatakan bahwa faktor-faktor yang mempengaruhi prestasi kerja adalah faktor kemampuan dan faktor motivasi.

Berdasarkan pendapat teori di atas, jelas dapat diketahui bahwa terdapat berbagai faktor yang mempengaruhi prestasi berusaha dimana salah satunya adalah faktor kemampuan yang dikaitkan dengan kekuatan atau daya saing yang dimiliki individu. Kemudian konsep daya saing itu sendiri menurut Wijaya (2007: 13) daya saing adalah sebagai kemampuan yang dimiliki dalam menghasilkan hasil yang tinggi. Sedangkan menurut Mitriani dalam Preffer (2007: 109) daya saing adalah karakteristik yang mendasari seseorang dan berkaitan dengan efektifitas prestasi kerja individu dalam pekerjaannya. Menurut Ubaedy (2009: 4) menyatakan daya saing sama dengan kompetensi yang berarti kecakapan atau kesiapan. Kata saing atau persaingan atau kompetisi yang artinya mencari bersama untuk menciptakan keunggulan yang lebih unggul. Ia menegaskan untuk bisa memenangkan persaingan itu, tentulah dibutuhkan kekuatan atau kesiapan atau alat, dimana senjata yang digunakan untuk bersaing adalah mengumpulkan kesiapan atau kekuatan.

Oleh karena daya sama dengan kompetensi maka dijelaskan Nastiti (2004: 19) kompetensi seringkali dikaitkan dengan arti "mampu" atau berkualitas untuk mengerjakan sesuatu atau suatu pekerjaan, misal dalam pengelolaan sumber daya manusia (SDM) khususnya pada perencanaan karir, karyawan yang akan dipromosikan adalah karyawan yang dianggap memiliki kompetensi tinggi, sementara karyawan yang tidak berkualitas dianggap tidak memiliki kompetensi tinggi (tidak mampu atau tidak berkualitas). Untuk hal tersebut di atas, maka kata kompetensi membahas mengenai suatu hasil kerja karyawan atau keberhasilan seseorang dalam mengerjakan tugasnya dengan efektif (output model) dan mengenalnya dengan sebutan kompeten. Di sisi lain, kata kompetensi sering dianggap sebagai suatu yang dipersyaratkan/diinginkan untuk (akan) mengerjakan suatu pekerjaan pada peran dan jabatan tertentu (input model) disebut kompetensi/competency.

Menurut Safri Nurmantu (2007: 90) memberikan pengertian kompetensi adalah untuk mencapai kinerja yakni kemampuan untuk menyusun dan menggunakan sumbersumber manusia, uang, bakat dan waktu dalam waktu yang terbaik.

Menurut Soetjipto (2007: 97) menjelaskan bahwa pengertian keunggulan kompetitif (daya saing) merupakan posisi unik yang dikembangkan dalam menghadapi pesaing dan berusaha mengungguli mereka secara konsisten. Kemudian menurut Khaidir Saib (2008: 1) daya saing dalam diri manusia terdiri dari kekuatan-kekuatan yang dapat 
membawa diri kepada keberhasilan, diantaranya adalah kekuatan insaniah, kekuatan akal, kekuatan nafsu, kekuatan hati nurani dan kekuatan emosional, jika kekuatan tersebut yang merupakan daya saing dalam diri dioptimalkan, maka akan mudah untuk mencapai keberhasilan.

Menurut Moekijat (2008: 117) daya saing seseorang membutuhkan persyaratan, dimana persyaratan ini biasanya berkaitan dengan pelatihan, pengalaman, kemampuan khusus, kecerdasan, ingatan, kegiatan yang berhubungan dengan pancaindera, perasaan, pendengaran, penglihatan dan perangai.

Kemudian Usman (2002:14) memberikan pengertian kompetensi sebagai kemampuan dalam melaksanakan kewajibankewajiban secara bertanggung jawab dan layak. Dari sisi lain berkaitan dengan kompetensi Prayitno (2002: 87) mengatakan bahwa: kompetensi merupakan pengetahuan, keterampilan, nilai, sikap dasar yang direfleksikan dalam kebiasaan berpikir dan bertindak yang bersifat dinamis, berkembang, dan dapat diraih setiap waktu. Kebiasaan berpikir dan bertindak secara konsisten dan terus menerus memungkinkan seseorang menjadi kompeten, dalam arti memiliki pengetahuan, keterampilan, nilai, dan sikap dasar dalam melakukan sesuatu.

Berdasarkan uraian tersebut maka dapat diketahui daya saing adalah suatu kecakapan atau kesiapan untuk menciptakan keunggulan yang lebih unggul dalam hal ini kecakapan yang dimiliki oleh pengusaha industri kecil dalam membangun usahanya.

Menurut Safri Nurmantu (2007: 1) dimensi daya saing adalah jantung kinerja perusahaan dalam pasar bersaing. strategi bersaing untuk dapat mencapai keunggulan bersaing adalah dengan keungulan biaya, diferensiasi dan fokus. Keunggulan bersaing adalah cara yang dapat dilakukan perusahaan untuk menerapkan strategi generik.

Kemudian menurut Khairul Muluk (2008: 41) dimensi daya saing, basis keunggulan bersaing tenaga kerja antara lain melalui efisiensi, produktivitas, kualitas, adaptasi dan inovasi. Menurut Palan (2007: 9) terdapat lima karakteristik yang dapat dijadikan ukuran daya saing antara lain: Pengetahuan, pengetahuan merujuk pada informasi dan hasil pembelajaran, seperti pengetahuan seorang ahli bedah tentang anatomi manusia. Keterampilan, merujuk pada kemampuan seseorang untuk melakukan suatu kegiatan. Konsep diri dan nilai-nilai, merujuk pada sikap, nilai-nilai dan citra diri seseorang. Karakteristik pribadi, merujuk pada karakteristik fisik dan konsistensi tanggapan terhadap situasi atau informasi. Motif, merupakan emosi, hasrat, kebutuhan psikologis atau dorongan lain yang memicu tindakan.

Berdasarkan uraian tersebut, maka dapat disimpulkan daya saing dapat dilihat dari dimensi pengetahuan; keterampilan; konsep diri dan nilai-nilai; karakteristik pribadi; dan motif.

Menurut Hartono (2013) bahwa pemilik usaha mikro dan kecil sektor informal mayoritas laki-laki, berusia kurang dari 25 tahun, kawin, memiliki anak, jenjang pendidikan perguruan tinggi dan memiliki pengalaman yang sesuai, waktu kerja lebih dari 36 jam, punya keterampilan, penghasilan awal berdiri kurang dari lima puluh juta, penghasilan saat ini kurang dari tujuh belas juta, modal awal berdiri kurang dari dua puluh juta, modal saat ini kurang dari enam puluh juta, asset awal berdiri kurang dari lima ratus juta rupiah, asset saat ini kurang dari satu milyar rupiah, profit awal berdiri kurang dari empat puluh lima juta rupiah dan profit saat ini kurang dari dua ratus lima puluh juta rupiah dan mayoritas berjenis usaha produk.

Rosita (2013), meneliti tentang motivasi dan kompetensi pengaruhnya terhadap kesuksesan pengusaha wanita. Hasilnya menunjukkan temuan, bahwa motivasi dan kompetensi berpengaruh secara simultan terhadap kesuksesan pengusaha wanita dan motivasi memiliki pengaruh dominan terhadap kesuksesan pengusaha wanita. Dari hasil perhitungan regresi berganda kompetensi tidak berpengaruh signifikan terhadap kesuksesan pengusaha wanita. 
Banu Siswoyo (2009) meneliti tentang pengembangan jiwa kewirausahaan di kalangan dosen dan mahasiswa. Hasil penelitiannya menunjukkan bahwa masalah pengangguran menjadi masalah yang sangat serius, dan praktik kewirausahaan sebagai salah satu solusinya. Semakin tinggi pendidikan seseorang, semakin rendah kemandirian dan semangat kewirausahaannya. Sebagian besar lulusan Perguruan Tinggi lebih siap sebagai pencari kerja, daripada sebagai pencipta kerja. Masa depan wirausahawan digambarkan akan terus cemerlang. Pembekalan dan penanaman jiwa entrepreneur pada mahasiswa diharapkan dapat memotivasi mahasiswa menjadi wirausahawan yang tangguh, ulet dan mandiri. Kewirausahaan merupakan persoalan penting didalam perekonomian suatu bangsa yang sedang mambangun. Kemajuan atau kemuduran ekonomi suatu bangsa ditentukan oleh keberadaan dan peranan dari kelompok entrepreneur.

\section{METODE}

Penelitian ini menggunakan metode kuantitatif. Populasi dalam penelitian ini adalah seluruh pengusaha industri kecil yang terdaftar pada Disperindag Kota Pekanbaru dengan jumlah 1.545 orang yang tersebar pada lima kelompok usaha yakni usaha industri pangan, pakaian, kimia dan bahan bangunan, logam dan elektronika dan kerajinan. Sampel adalah bagian dari jumlah dan karakteristik yang dimiliki oleh populasi. Mengingat populasinya yang relatif tidak terjangkau maka ditetapkan sampel. Metode pengambilan sampel dilakukan dengan menggunakan rumus Slovin. Untuk mendapatkan data dan informasi serta bahan-bahan lainnya yang diperlukan dan studi kepustakaan. Data penelitian dianalisis dengan menggunakan teknik analisa jalur.

\section{HASIL}

Prestasi berusaha adalah suatu tingkah laku sebagai keluaran dari suatu proses berbagai macam komponen kejiwaan yang melatar belakanginya atau meghasilkan lebih banyak, dan berkualitas lebih baik, dengan usaha yang sama. Dimensinya yakni produksi (keuntungan, penjualan, pangsa pasar, pelanggan); efisiensi (keluaran dengan masukan); kepuasan (sikap, kesejahteraan); ketidakpastian (persaingan, keinginan pelanggan, kualitas); dan kelangsungan hidup. bahwa jawaban responden tentang prestasi berusaha pengusaha industri kecil di Kota Pekanbaru tergolong baik yakni dengan skor 3,9 atau $77,9 \%$.

Daya saing adalah suatu kecakapan atau kesiapan untuk menciptakan keunggulan yang lebih unggul dalam hal ini kecakapan yang dimiliki oleh pengusaha IKM dalam membangun usahanya. Dimensinya antara lain: pengetahuan, pengetahuan merujuk pada informasi dan hasil pembelajaran, seperti pengetahuan seorang ahli bedah tentang anatomi manusia; keterampilan, merujuk pada kemampuan seseorang untuk melakukan suatu kegiatan; konsep diri dan nilai-nilai, merujuk pada sikap, nilai-nilai dan citra diri seseorang; karakteristik pribadi, merujuk pada karakteristik fisik dan konsistensi tanggapan terhadap situasi atau informasi; dan motif, merupakan emosi, hasrat, kebutuhan psikologis atau dorongan lain yang memicu tindakan. bahwa jawaban responden tentang daya saing industri kecil di Kota Pekanbaru tergolong baik dengan skor 3.38 atau $67,6 \%$.

Berdasarkan hasil penelitian diperoleh data sebagai berikut:

\begin{tabular}{|l|c|c|c|c|}
\hline Model & $\mathrm{R}$ & $\begin{array}{c}\mathrm{R} \\
\text { Square }\end{array}$ & $\begin{array}{c}\text { Adjusted R } \\
\text { Square }\end{array}$ & $\begin{array}{c}\text { Std. Error of the } \\
\text { Estimate }\end{array}$ \\
\hline 1 & $.579^{\mathrm{a}}$ & .335 & .328 & 8.76143 \\
\hline
\end{tabular}

a. Predictors: (Constant), Daya saing

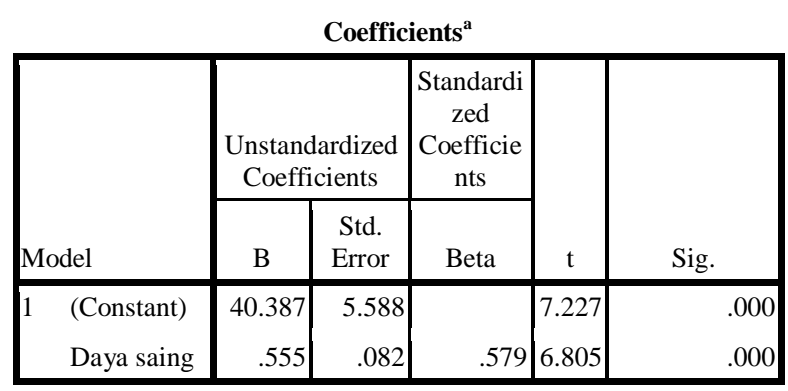


Nilai nilai probabilitas sign sebesar 0,000 dan nilai t hitung sebesar 6,805. Ini berarti bahwa Nilai t hitung dibandingkan dengan $\mathrm{t}$ tabel yakni $6,805>1,980 \mathrm{Ho}$ ditolak artinya signifikan. Juga dapat dilihat dari nilai siginifikansi sebesar $0,000 \leq 0,05$ maka Ho diterima dan Ha ditolak, artinya signifikan. Jadi, dapat diketahui bahwa daya saing berpengaruh signifikan terhadap prestasi berusaha pengusaha industri kecil di kota Pekanbaru.

Daya saing berpengaruh terhadap prestasi berusaha pada industri kecil di kota Pekanbaru". Dari hasil pengolahan data diketahui besarnya pengaruh daya saing terhadap prestasi beruasha dinyatakan dengan koefisien sebesar 0,555. Ini menunjukkan bahwa daya saing pengusaha pada industri kecil mampu membuat pengusaha berprestasi.

\section{PEMBAHASAN}

Dari hasil perhitungan diketahui bahwa pengaruh daya saing terhadap prestasi berusaha melalui kewirausahaan lebih besar bila dibandingkan dengan pengaruh lingkungan bisnis terhadap prestasi berusaha melalui kewirausahaan, dengan total pengaruh 0,135 . Hal ini disebabkan bekerja sebagai pengusaha atau menjadi pengusaha membutuhkan daya saing yang dapat mendukung berusaha seperti pendidikan, pengalaman, visi dan misi serta strategi. Hal ini sejalan dengan apa yang dikatakan Hartono (2013), bahwa pemilik usaha mikro dan kecil sektor informal mayoritas laki-laki, berusia kurang dari 25 tahun, kawin, memiliki anak, jenjang pendidikan perguruan tinggi dan memiliki pengalaman yang sesuai, waktu kerja lebih dari 36 jam, punya keterampilan, penghasilan awal berdiri kurang dari lima puluh juta, penghasilan saat ini kurang dari tujuh belas juta, modal awal berdiri kurang dari dua puluh juta, modal saat ini kurang dari enam puluh juta, asset awal berdiri kurang dari lima ratus juta rupiah, asset saat ini kurang dari satu milyar rupiah, profit awal berdiri kurang dari empat puluh lima juta rupiah dan profit saat ini kurang dari dua ratus lima puluh juta rupiah dan mayoritas berjenis usaha produk. Dilihat dari hasil tabulasi silang antara jenjang pendidikan dan penentuan target pelanggan saat ini, mayoritas yang sudah menetapkan target pelanggan adalah responden berpendidikan SMA dan perguruan tinggi. Dari hasil tabulasi silang antara jenjang pendidikan dan promosi saat ini, mayoritas responden berpendidikan SMA dan perguruan tinggi menggunakan getok tular. Dari hasil tabulasi silang antara usia dan promosi saat ini, mayoritas responden yang berusia kurang dari 25 tahun menggunakan cara penjualan langsung. Dari hasil tabulasi silang antara usia dan distribusi saat ini, mayoritas responden yang berusia 25-35 tahun melakukan distribusi ecer sendiri.

Juga didukung oleh Khairina (2008), meneliti tentang Pengaruh Sikap Kewirausahaan Terhadap Prestasi Usaha Mikro, Kecil Dan Menengah Di Sumatera Barat. Dari hasil uji yang dilakukan menunjukan secara simultan seluruh sikap kewirausahaan yang di uji berpengaruh dan signifikan terhadap prestasi usaha mikro, kecil dan menengah di Sumatera Barat. Secara parsial sikap kewirausahaan yang di uji berpengaruh dan signifikan terhadap prestasi usaha mikro, kecil dan menengah di Sumatera Barat. Penelitian ini memberikan implikasi pada usaha mikro, kecil dan menengah untuk dapat lebih menanamkan sikap kewirausahaan agar dapat meningkatkan prestasi usaha.

Selanjutnya dari tiga variabel yang mempengaruhi prestasi berusaha pengusaha industri kecil di Kota Pekanbaru diketahui bahwa secara langsung variabel lingkungan bisnis memberikan pengaruh paling besar yaitu sebesar 0,316. Prestasi berusaha membutuhkan dukungan pemerintah pemerintah, dukungan lingkungan yang kondusif memberikan kesempatan bagi pengusaha industri kecil untuk bertahan terhadap berbagai bentuk persaingan yang terkadang tidak mampu mereka hadapi sendiri. Hal ini sesuai dengan yang dikatakan oleh Endang Sri (2011) ketidakpastian lingkungan hanya berpengaruh signifikan 
pada hubungan antara preferensi pada inovasi dengan kinerja UKM. Walaupun preferensi pada inovasi relatif tinggi namun mereka tergolong risk averse dan cenderung mencari lingkungan yang ketidakpastiannya rendah sehingga kinerjanya belum maksimal; ketidakpastian lingkungan hanya mempengaruhi hubungan antara preferensi pada inovasi dengan kinerja UKM pada pengusaha laki-laki, pengusaha muda, dan pengusaha berpendidikan menengah dan tinggi. Namun untuk kecenderungan mengambil risiko, hanya pengusaha laki-laki yang berkinerja lebih tinggi jika berada pada ketidakpastian lingkungan tinggi dari pada rendah, sedangkan untuk klasifikasi usia dan pendidikan tidak; budaya kolektivistik dan penghindaran terhadap ketidakpastian yang tinggi telah membentuk karakteristik pribadi pengusaha dengan nilai-nilai sosial, kekeluargaan, tenggang rasa dan nilai religius yang sangat tinggi. Melalui proses pembelajarannya mengelola UKM semakin memperkuat internalisasi nilai-nilai tersebut dan mewarnai setiap strategi bisnis yang digunakan dan pada gilirannya mempengaruhi kinerja UKM.

\section{SIMPULAN}

Berdasarkan uraian di atas dapat ditarik beberapa kesimpulan bahwa daya saing berpengaruh terhadap prestasi berusaha pada industri kecil di kota Pekanbaru dengan besarnya pengaruh daya saing terhadap prestasi beruasha dinyatakan dengan koefisien bermakna alasan ingin sukses karena memiliki potensi untuk sukses sebagai modal bagi pengusaha berusaha sehingga usaha memperoleh keuntungan yang terus meningkat dan juga produk yang dihasilkan semakin efisien.

Kepada pemerintah kota Pekanbaru untuk dapat memberikan dukungan kepada pengusaha industri kecil yang memiliki daya saing unggul melalui menciptakan lingkungan bisnis yang sehat dan kondusif yakni melalui dukungan permodalan dan pemasaran, sehingga dapat membantu pengusaha industri kecil dalam mengembangkan produk serta memasarkannya ke mancanegara.

Kepada pengusaha industri kecil dalam rangka meningkatkan prestasi berusaha perlu meningkatkan daya saing dengan terus belajar dan menimba pengalaman dari berbagai sumber dan juga sehingga dapat dijadikan kekuatan untuk bertahan dan mengembangkan usaha ke depan.

\section{DAFTAR RUJUKAN}

Abdullah Abidin, 2012, Pengembangan Usaha Micro Kecil Dan Menengah (Umkm) Sebagai Kekuatan Strategis Dalam Mempercepat Pembangunan Daerah, STIE Nobel Makasar.

Amos Neolaka. 2008. Kesadaran Lingkungan, Rineka Cipta, Jakarta.

Anwar Prabu Mangkunegara. 2005. Manajemen Sumber Daya Manusia Perusahaan., PT. Remaja Rosdakarya, Bandung.

An. Ubaedy. 2007. Kompetensi kunci dalam berprestasi, career, business \& life, Bee Media Indonesia, Jakarta.

BPS. 2012. Pekanbaru dalam Angka, Kerjasama Bdan Pusat Statistik Kota Pekanbaru dengan Badan Perencanaan Pembangunan Daerah Kota Pekanbaru, Pekanbaru

BPS. 2011. Pekanbaru dalam Angka, Kerjasama Badan Pusat Statistik Kota Pekanbaru dengan Badan Perencanaan Pembangunan Daerah Kota Pekanbaru, Pekanbaru

Chatab, Nevizond. 2007. Profil Budaya Organisasi, mendiagnosis Budaya dan Merangsang Perubahan, Alphabeta, Bandung. 
Edy Sutrisno. 2010. Budaya Organisasi, Kencana Prenada Media Group, Jakarta.

Fandi Tjiptono. 2000. Strategi Bisnis Modern, Andi, Yogyakarta

Heidjrachman, Suad Husnan. 2000. Manajemen Personalia, Edisi 4, BPFE, Yogyakarta.

Henry Simamora. 2004. Manajemen Sumber Daya Manusia. Edisi Ke-3. STIE YKPN.

Ishak Arep dan Hendri Tanjung. 2003. Manajemen Motivasi, Gramedia, Jakarta.

Istijanto. 2006. Riset Sumber Daya Manusia, PT. Gramedia Pustaka Utama, Jakarta.

Kasmir. 2007. Kewirausahaan, PT

RajaGrafindo Perkasa, Jakarta.

Khaidir Saib. 2008. Manusia dan Alat peraba Kebenaran (Al Quwwah Al Insaniyah), Unri Press, Pekanbaru.

Khairul Muluk. 2008. Knowledge Management, Pengantar M. Irfan Islami, Lembaga penerbit dan dokumentasi FIA Unibraw, Malang

Leonardus Saiman. 2009. Kewirausahaan, Teori, Praktik dan Kasus-kasus, Salemba Empat, Jakarta.

Moh. Pabundu Tika. 2010. Budaya organisasi dan peningkatan kinerja perusahaan, Bumi Aksara, Jakarta.

Miftah Thoha. 2002. Pembinaan Organisasi, Proses diagnose dan intervensi, RajaGrafindo Persada, Jakarta.
2008. Perilaku Organisasi Konsep

Dasar dan Aplikasinya, Raja Grafindo Persada, Jakarta.

Moekijat. 2008. Analisis Jabatan, Mandar Maju, Bandung.

Moenir. 2000. Manajemen Pelayanan Umum di Indonesia, Bumi Aksara, Jakarta.

Nasution, M.N. 2005. Manajemen Mutu Terpadu, Ghalia Indonesia, Bogor.

Panji Anoraga. 2005. Psikologi Kerja, Rineka Cipta, Jakarta.

Riduwan. 2008. Cara Menggunakan dan Memakai Analisis Jalur (Path Analysis), Alpabeta, Bandung.

Safri Nurmantu. 2007. Budaya Organisasi dari Chaster I Barnard ke Michael E. Porter, Selo Sumarjan Recearch Centre, Fisip UI, Jakarta.

Soetjipto. 2007. Paradigma Baru Manajemen Sumber Daya Manusia, Editor Usmara, Amara Books, Yogyakarta.

Sopiah. 2008. Perilaku Organisasional, Andi Offset, Yogyakarta.

Sugiyono. 2012. Metode Penelitian Pendidikan, Pendekatan Kuantitatif, Kualitatif dan $R \& D$, Alpabeta, Bandung

Suharsimi Arikunto. 2005. Prosedur Penelitian Suatu Pendekatan Praktik, Edisi Revisi, Rhineka Cipta, Jakarta

Suhendar Sulaiman. 2013. Cara Mudah Menjadi Wirausahawan Sukses, Bahan Ajar Mata Kuliah Kewirausahaan, Universitas Muhammadiyah Jakarta. 
Surya Dharma. 2004. Manajemen Kinerja, Falsafah Teori dan Penerapannya, Pustaka Pelajar, Yogyakarta.

Surya Dharma. 2005. Manajemen Kinerja Falsafah Teori dan Penerapannya, Pustaka Pelajar, Jakarta.

Taliziduhu Ndraha. 2005. Teori Budaya Organisasi, Rineka Cipta, Jakarta.

Tb. Sjafri Mangkuprawira. 2003. Manajemen Sumber Daya Manusia Strategik, Ghalia Indonesia, Jakarta.

Thoha, Miftah. 2008. Perilaku Organisasi Konsep Dasar dan Aplikasinya, RajaGrafindo Persada, Jakarta.

Tirta Dwi. 2013. Media Informasi, Jakarta.

Ubaedy. 2007. Kompetensi kunci dalam Berprestasi, Career, Business dan Life, Bee Media Indonesia, Jakarta.

Usman. 2002. Menjadi Guru Profesional, Remaja Rosdakarya, Bandung

Keputusan Menteri Koperasi dan Pembinaan Pengusahan Kecil Nomor 961/KEP/M/XI/1995

SK Mentri Perindustrian dan Perdagangan No.254/MPP/7/1997

AA. Ayu Laksmidewi TP, 2010, pengaruh faktor kekompakan, motivasi, dan peran kepemimpinan ketua kelompok terhadap keberhasilan usaha perikanan, Jurnal Ekonomi dan Bisnis, Vol 4. NO 2 Juli 2010.

Bambang Banu Siswoyo. 2009. Pengembangan Jiwa Kewirausahaan di Kalangan Dosen dan Mahasiswa, Jurnal Ekonomi Bisnis Vol 14 No. 2 Juli 2009

Endang Sri. 2011. Peran Ketidakpastian Lingkungan pada Hubungan antara
Karakteristik Pribadi Pengusaha dengan Kinerja UKM Sektor Industri Di Malang Jawa Timur (Studi dengan Trianggulation Mixed Method). Disertasi, Prodi Pendidikan Ekonomi Pascasarjana UM.

Hartono. 2013. Analisa Faktor Individual Pengusaha Mikro Dan Kecil Sektor Informal Dan Hubungannya Terhadap Kinerja Bisnis Di Jawa Timur, Jurnal Agora, Vol 1, No 3

Khairina, Khairina. 2008. Pengaruh Sikap Kewirausahaan Terhadap Prestasi Usaha Mikro, Kecil Dan Menengah Di Sumatera Barat. Tesis, Fakultas Ekonomi.

M. Syahirman Yusi. 2012. Analisis Kondisi Internal Dan Eksternal Usaha Kecil di Kota Palembang Implikasinya Terhadap Pencapaian Hasil Usaha, Jurnal Orasi Bisnis Edisi ke-VIII, November 2012.

Rofiaty. 2010. Pengaruh Turbulensi Lingkungan, Knowledge Sharing Behavior, Dan Strategi Inovasi Terhadap Kinerja Usaha Kecil Menengah Kerajinan Sepatu Kulit Di Mojokerto. Jurnal EkonomikaBisnis, Vol. 02 No. 02

Rosita. 2013. Motivasi Dan Kompetensi Pengaruhnya Terhadap Kesuksesan Pengusaha Wanita. Jurnal Peran Perbankan Syariah Dalam Penguatan, Tesis, Fakultas Ekonomi dan Bisnis Universitas Brawijaya Malang.

Saparuddin. 2011. Pengaruh Kemitraan Usaha Terhadap Kinerja Usaha Pada Usaha Kecil Menengah (UKM) Dan Koperasi Di Kabupaten Jeneponto Sulawesi Selatan, Jurnal Volume IX, Nomor 2, Agustus 2011. 
Wina Junia. 2011. Pengaruh Jiwa Kewirausahaan dan Motivasi Terhadap Kinerja Usaha Para Pengusaha Butik di Istana Plaza Bandung. Tesis, Fakultas Ekonomi Manajemen Universitas Komputer Indonesia
Yohanes Rante. 2010. Pengaruh Budaya Etnis dan Perilaku Kewirausahaan Terhadap Kinerja Usaha Mikro Kecil Agribisnis di Provinsi Papua. Jurnal Agora, Vol 12, No 2. 